\title{
Training and Job Security in Oil and Gas Companies in Rivers State, Nigeria
}

\author{
Fred, Enobong Udoh* \\ Ignatius Ajuru University of Education, Rumuolumeni, P.M.B 5047, Port Harcourt, Nigeria \\ Ugwulebo, Loveline Ngozi \\ Ignatius Ajuru University of Education, Rumuolumeni, P.M.B 5047, Port Harcourt, Nigeria \\ Chima, Caroline Ekwutosi \\ Ignatius Ajuru University of Education, Rumuolumeni, P.M.B 5047, Port Harcourt, Nigeria
}

\begin{abstract}
The study examined the relationship between training and job security in oil and gas companies in Rivers State, Nigeria. The survey was based on four selected oil and gas companies with a sample size of 262 staff. The aim of the study is to examine the impact of training on job security in oil and gas companies. Questionnaires were administered to staff of the selected companies. Three hypotheses were formulated and tested. Statistical tool of Pearson Product Moment Correlation Coefficient was used to test the strength and direction of the relationship between the variables. Findings revealed that there is a significant relationship between training and job security. Thus it was concluded that training seeks to educate employees on the product, services and ethics of the organization and to clarify them on the set task. The training is designed to align with the needs of the employer (organization) and assist to achieve potential outcomes. Thus, it was recommended that training of employees in the oil and gas companies should be paramount considering the complexity of the job done there. Also oil and gas companies should enforce quality training programs, as this is capable to ensure that the right people with the right mind are retained to sufficiently contribute to the success of the organization.
\end{abstract}

Keywords: Employability skills, Employment contract, Job security, Training, Work experience.

DOI: $10.7176 / \mathrm{EJBM} / 13-23-08$

Publication date: December $31^{\text {st }} 2021$

\section{INTRODUCTION}

Employee activities have been mostly used to observe organizational performance and the organizations come in all shapes and sizes which frequently exhibit more differences than similarities. However, one predominant factor to all organizations is that success is greatly dependent on the skills, knowledge, and experience of their employee (Harrison, 2015). These skills and knowledge are gotten through training. In the current competitive environment, which is anchored by the knowledge economy, the attributes and competencies of the employee are vital elements in organization's competitiveness. Certainly, greatly trained and greatly skilled subordinates or employee can enhance productivity and the quality of goods and services (Blair \& Sisakhti, 2007). This can lead to positive changes in processes and the delivering of quality service to clients, thereby enhancing the organization's competitiveness and performance. Thus, training produces tangible outcomes, such as enhancing productivity, superior products and services, and resource maximization as well as optimization (Hiltrop, 2019). Training also produces intangible results such as high self-esteem, high morale and the satisfaction of subordinates as a result of additional skills, knowledge and abilities (SKAs).

Organizations that systematically train and develop their employee, develop their market value more favourably thus, there will be higher productivity and growth.

It is therefore not surprising that in modern times, the emphasis on training and the acquisition of new skills are increasingly becoming the key for organizations to attain enduring outcomes such as retention and commitment, because failure of training could be catastrophic to the organization. One should note that dynamic environments and changing customer needs require unique solutions and modern employee skills to grant superior services and products. Training is very important in the oil and gas sector because of the complexity of jobs done there. When training is given to employees, it tends to give a sense of satisfaction, and job security, which is often reciprocated with commitment and loyalty to the organization. 


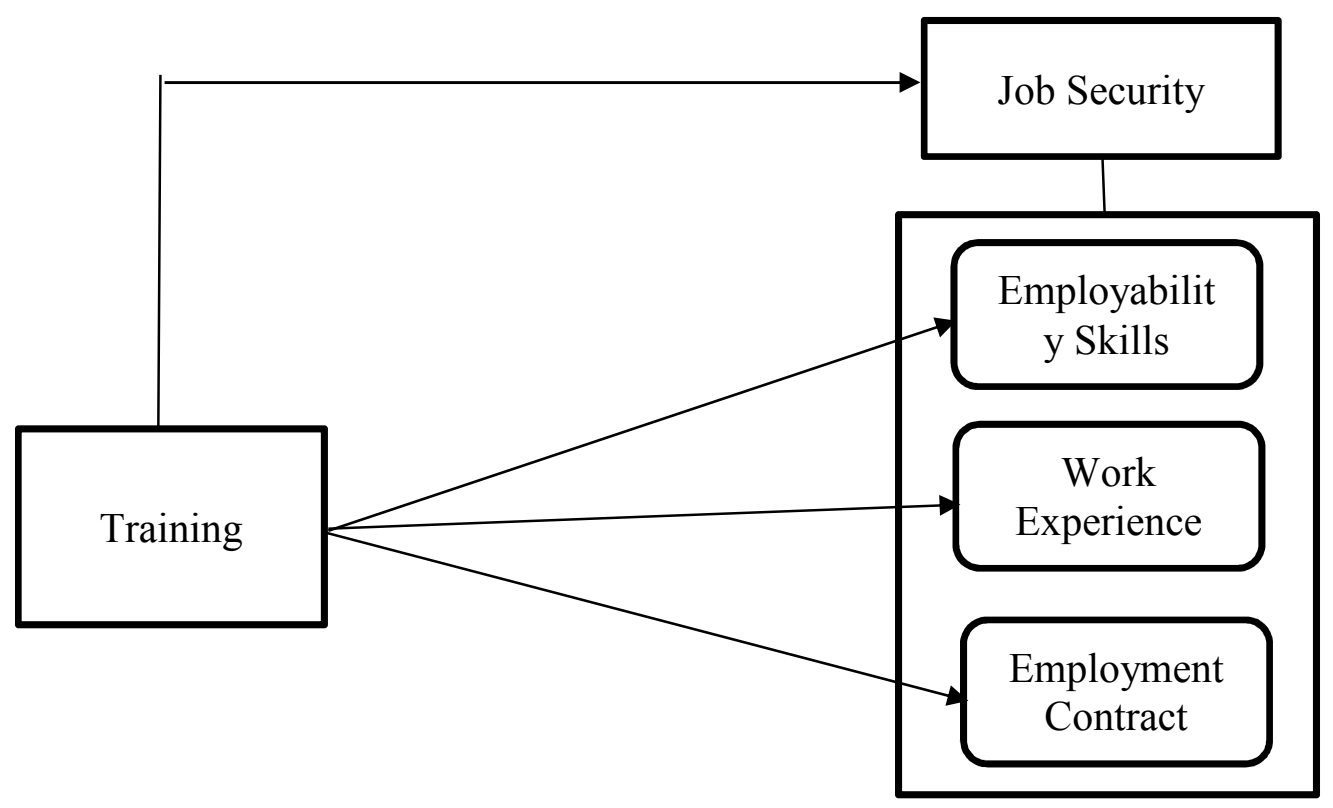

Figure 1: Operational Framework of the Relationship between Training and Job Security Source: Researcher (2021).

\section{Aim of the Study}

The aim of the study was to examine the impact of training on job security in oil and gas companies in Rivers State, Nigeria.

\subsection{Research Questions}

i. What is the relationship between training and employability skills in oil and gas companies in Rivers State?

ii. What is the relationship between training and work experience in the oil and gas companies in Rivers State?

iii. What is the relationship between training and employment contract in oil and gas companies in Rivers State?

\subsection{Research Hypotheses}

Ho1: There is no significant relationship between training and employability skills.

Ho2: There is no significant relationship between training and work experience.

Ho3: There is no significant relationship between training and employment contract.

\section{Training}

Training is a function of human resource management concerned with organizational activities aimed at improving the performance of individuals and groups in organizational settings. Training scheme increases the organization's specificity of employee skills, which in turn, increases employee productivity and reduces job displeasure that results in employee turnover (Huselid, 2011). Becker and Huselid (2006) argued that the economic yields of extensive training is more likely to be captured by the organization if employees are motivated to stay and contribute to the firm's achievement nurtured in part by selective recruitment, competitive pay packages and team oriented work environments. Empirical research shows that organizations with successful training and development scheme do experience lower turnover (Fey, et al., 2017).

Conversely, some studies have suggested that comprehensive training scheme can influence employee retention, productivity and organizational effectiveness positively (Oregon-Sanchez, et al., 2017). Training is used to enhance specific skills and correct performance issues to empower employee with the skills required for contemporary and imminent job requirement (Gomez-Mejia, et al., 2005; Gold, 2001; Wood \& De Menezes, 2008). Noe, et al., (2015) defines training as a planned effort to facilitate the learning of job related skills, knowledge, and behaviour by employees of an organization.

However, the extent to which the management of oil and gas organizations are able to create and sustain a training scheme may depend significantly on their value on training and organizational goals and objectives. The researcher conceptualizes training as the act of imputing new skills and knowledge through an organized process into the employee for organizational benefit. Therefore, training can be in form of (a) mentoring (b) on the job training (c) off the job training. These are the types of trainings granted in oil and gas firms:

i. Mentoring: The term mentoring as used in this study connotes the care and tutoring given to an inexperienced employee by an experienced employee in the organization. It is used in organisations to aid induction and 
help new employee acclimatise and integrate into the working environment. Mentoring grants support and self-development opportunity for individuals to help them reach their potential (Gold, 2001). Mentoring is important, not only because of the knowledge and skills employee can learn from mentors, but also because mentoring grants professional socialization and personal support to facilitate success in organization and beyond. Quality mentoring greatly enhances employees' chances for success (Smith \& De Cronje, 2013).Workplace mentoring scheme in the oil and gas organizations help employee do the right thing by exposing them to senior employees that know how to do the right thing. This helps the employee perform more effectively and gives the employee more satisfaction. Higher job satisfaction leads to increased productivity and reduced turnover.

ii. On-The-Job Training: The term on-the-job training as used in this study refers to the training an employee receives in the cause of doing his/her job in the organization. It is a form of training that takes place in a normal working situation, which is sometimes called direct instruction. It is a one-on-one training located at the job site where someone who knows how to do a task shows another how to perform it. This type of training is very much obtainable in the oil and gas sector due to its complex nature. According to Smith and De Cronje (2013) there have been several recent studies on managerial learning and skills development that result from on-the-job experience. This research suggests that employee learn most from assignments that are very difficult and challenging.

iii. Off-The-Job Training: The term off-the-job training as used in this study connotes the type of training given to an employee outside the work environment for a particular period of time. This form of training takes place away from the immediate workplace. It includes more general skills and knowledge that is useful for work. In terms of this type of training, small groups of eight to fourteen individuals who are strangers to each other are usually grouped together and assisted by a trainer. During the discussion, employee discuss themselves, their feelings, and the group process (Warnich \& Grobler, 2016).

\subsection{The Concept of Job Security}

The term job security as used in this study refers to the continuous retention of an employee in an organization. The concept of job security started gaining popularity in the recent times as a result of economic pressures on organizations. This could be the reason why Adebayo and Lucky (2012), agreed that job security has become indispensable in employee and organization's preference list, particularly due to economic reasons. Thus, it has become one of the most crucial and vital factors among the employee preference list as well as the organization (Schappel, 2012; Klynveld Peat Marwick Goerdeler, [KPMG] 2010). Globally, about 75\% of the employee preferred to keep their jobs compared to other factors in their preference list (Towers Watson [TW], 2010). This indicates that job security is as vital as the employee' salary and healthcare (KPMG, 2010).

Presently, the most vital desire of every employee is to keep their jobs for as long as they wish. In this view, it implies that job security has become the most determinant and key element influencing an employee's decision on whether to join an organization or not (TW, 2010). Job security creates a climate of confidence among employees which cultivates their commitment on the organization's workforce (Kalleberg \& Rognes, 2000).

Job security requires a certain degree of reciprocity. Firstly, a company must signal a clear message that jobs are secure; then, employee believing that this is true, feel confident and commit themselves to expend extra effort for the company's benefits. For the job of an employee to be secured, skills, experience and the type of contract signed must come into play.

\section{i. Employability Skills}

The term employability skills as used in this study refers to the skills possessed by an employee that increases his/her chances of been employed and retained in an organization.

Employability can be defined as a set of achievements - skills, understandings and personal attributes that make employee more likely to gain employment and be successful in their chosen occupations, which benefits themselves, the workforce, the community and the economy (Brown \& Hesketh, 2004). According to International Labour Organization [ILO] (2013) defines employability skills as the skills, knowledge and competencies that enhance a worker's ability to secure and retain a job, progress at work and cope with change, secure another job if he/she so wishes or has been laid off and enter more easily into the labour market at diverse periods of the life cycle.

Organization hire persons for their skills and then put them in sections where such skills will be utilized effectively. Employability skill is a group of essential abilities that involve the development of a knowledge base, expertise level and mind-set that is increasingly necessary for success in the modern workplace (Roehling, et al., 2000). Employability skills are typically considered essential qualifications for many job positions and hence have become necessary for an individual's employment success at just about any level within a business environment (Juliane, 2020a).

It is not the same as getting a job, rather it implies to an employee's capacity to survive in a job and be able to move between jobs, thus remaining employable throughout life (business dictionary, 2013b). It is the possession 
of skills and competence to survive in a work situation. Skills necessary for self-advocacy and networking to cope with the changing circumstances, be active in the maintenance of continuous learning and capable of working within changing teams (Deloitte, 2010).

Employability skill is an assessment of the economic worth of an employee at the time of employment. It can also be defined as the enhanced capacity to secure and maintain employment (Saravanan, 2009). Employability skills are core skills and traits needed in nearly every job. These are the general skills that make someone desirable to an organization.

They are soft skills that allow you to work well with others, apply knowledge to solve issues and fit into any work environment. They also include the professional skills that enable you to be successful in the workplace. These are also seen as transferable skills because you can apply them to a job in any industry (Hind \& Moss, 2011).

\section{ii. Work Experience}

The term work experience as used in this study is used to capture the experiences an employee brings to the organization that relates to the previous jobs done in similar organization.

Work experience is perhaps one of the most encountered concepts in personnel research and practice. Work experience is relevant for many employee functions such as selection (Ash \& Levine, 2015), training (Ford, et al., 2012), and career development (Campion, et al., 2014; McCall, et al., 2008). Given the importance of work experience for employee practice and research, it is not surprising that a fair amount of research has examined the concept and its relationship with vital outcomes such as job security (Ash \& Levine, 2015).

Work experience is generally defined as events which occur in an individual's life that are perceived by the individual. Employee work experience is defined as cognitive experiences of employee in the organization, measured in relation to organizational climate, internal policies and leadership (Ford, et al., 2012). However, life events are clearly not discrete. Life is a fluid stream of experience events with no predominant factor system for delineating when an event ends and the other begins.

Work experience refers to events which are experienced by an individual which relate to the performance of some job. However, a number of measures can be used to represent an individual's level of work experience (Hofmann, et al., 2012).

Work experience should not be regarded as something that is intrinsically beneficial; something that is somehow 'good for the soul'. On the contrary, it is a means to an end and it is vital to keep the end in sight. The end is the learning that comes from the experience. Work experience offers a significant route to developing a range of employee attributes and plays a vital role in augmenting the higher education learning experience. Work experience is a process that is part of the whole spectrum of learning (Campion, et al., 2014). Work experience can offer the opportunity to develop skills that enable employees to be work-ready, that is be at the adaptive end of the enhancement continuum.

iii. Employment contract

The term employment contract as used in this study connotes the written or oral contract entered between the employer and the employee, where the former offers terms and conditions of employment and the latter renders services upon a reached agreement. An employment contract is a legally-binding document between an employee and employer. It typically details the expectations of the employment period. An employment contract, also known as an employee agreement, is a written document of the conditions of a job offer from an employer to a potential employee (Michael, 2019). It covers all of the terms of the new working relationship that will exist between the two parties. Typically, these documents will require signatures from both the employee and a representative of the company he or she is going to work for. Employment contracts are legally binding documents that grant information that protects both parties. Not every employee will be asked to sign an employment contract, and not every company uses them. Those who do use them do so for one purpose to establish a clear picture of the expectations of the employment period. It may also be useful in a legal dispute if it were to arise during or after employment (Michael, 2019).

A contract can completely negate at will employment in many cases and includes stipulations regarding promotions, rewards, duration and terminations which makes it a useful tool for enticing new employee. An employment contract is a legally enforceable agreement, either oral or written which defines terms and conditions of employment (Chang, 2008). The employment contract has been the key institution used as the basis of employment in enterprises (Zhu \& Campbell, 2002) facilitating harmonious labour relations by specifying the powers and duties of both employer and employee.

This not only grants a fundamental basis for protecting an employee's rights at work but also serves as the primary reference point for adjudicating disputes (Chang, 2008; Remington \& Cui, 2019). The contract lists the rights, expectations and obligations of both the company and the individual. It also states the duration and types of contract which determines if the employee's job is secured or not.

\subsection{Training and Job security}

Messmer (2000) found that one of the vital factors in job security is investment on employee training and career 
development. Organization always invests in the form of training on those workers from whom they expect to keep and give output on its investment. Tomlinson (2002) forwarded the view that organizations can keep the leading edge in this competitive world by having their employee well trained in the latest technologies.

A study conducted by Ronald and Lidewey (2006) revealed that the type of training and development plans put in place to develop the employee go a long way to determine the calibre of skills and knowledge they acquire which the employee will in turn bring into the organization which explains the commitment and job satisfaction of the employee which would decrease their intention to leave the organization. This implies that training participation has a positive effect on job security (internal and external) which retains employee.

No organization would dismiss its employees easily after spending huge sums of money on training. Training provides a special kind of job security that gives the employee satisfaction. Training is provided to workers in the oil and gas companies because of the complexity of the job done there, which reduces turnover and workers' intention to quit.

\section{METHODOLOGY}

Design: The study setting was a non-contrived setting, which means that subjects were in their natural environment. This study adopted a quasi-experimental design approach because it focused on more than three (3) subjects (organizations) and generalization was made. This study adopted a cross sectional survey method, which seeks to generate data at a given time.

Population and Sample Size: The target population of this study consists of all the oil and gas companies in Nigeria which was out of place, because it was greatly cumbersome to study all oil and gas companies in Nigeria, therefore, an accessible population was chosen. The accessible population for this study comprised of four (4) selected oil and gas companies in Rivers State with a population of 1,945 employees. Sample size of 320 employees was drawn using the Krejcie and Morgan (1970) Population Size Table.

Data Collection Methods: Primary data for this study was generated using structured questionnaire. Questionnaire copies were distributed to 320 oil and gas company workers in Rivers State; and was administered by the researcher and other assistants.

Measurement: An all-inclusive questionnaire was designed by the researcher. Training was measured using 7 items. Job security was measured using 8 items (employability skills -3 ; work experience -2 ; employment contract - 3) with each statement. Statements were all scaled on a 5-point Likert type scale. The researcher administered a total of 320 copies of the questionnaire to the respondents. Statistical tool of Pearson Product Moment Correlation Coefficient was used to test the strength and direction of the relationship between training and job security.

DATA RESULTS

Table 1 Questionnaire Response Rate

\begin{tabular}{lll}
\hline S/N & \multicolumn{1}{c}{ Questionnaires } & Frequency \\
\hline 1 & Number of questionnaires distributed & 320 \\
2 & Number of questionnaires returned & 262 \\
3 & Response Rate & $94 \%$ \\
\hline
\end{tabular}

Source: Field Survey, (2021)

The table 1 represents the response rate to the questionnaire items. 320 questionnaires were distributed to respondents, and 262 questionnaires returned back for the analysis. The response rate indicates $94 \%$ for the study.

Table 2 Gender of Respondents

\begin{tabular}{llccc}
\hline & & Frequency & Percent & Valid Percent \\
\hline Valid & Male & 206 & 78.6 & 78.6 \\
& Female & 56 & 21.4 & 21.4 \\
& Total & 262 & 100.0 & 100.0 \\
\hline
\end{tabular}

Source: Field Survey, (2021).

Table 2 shows the gender of our respondents. Among the two hundred and sixty two respondents, 206 representing $78.6 \%$ of the respondents were males, while $56(21.4 \%)$ indicated female as their gender. This indicates that males are more than female in the selected oil and gas companies of study. The huge margin shows that the oil and gas sector requires more male than females due to the strenuous job involved. However, this has no influence on the outcome of the study. 
Table 3 Marital Status of Respondents

\begin{tabular}{llccc}
\hline & & Frequency & Percent & Valid Percent \\
\hline Valid & Single & 74 & 28.2 & 28.2 \\
& Married & 188 & 71.8 & 71.8 \\
& Total & 262 & 100.0 & 100.0 \\
\hline
\end{tabular}

Source: Field Survey, (2021).

Table 3 shows the marital status of our respondents. Among the two hundred and sixty two respondents, 74 representing $28.2 \%$ of the respondents were singles, while 188 representing $(71.8 \%)$ indicated married as their status. This indicates that married workers are more than singles workers in the selected oil and gas companies of study and as such would demand for job security.

\section{Table 4 Age of Respondents}

\begin{tabular}{llccc}
\hline & Frequency & Percent & Valid Percent \\
\hline Valid & $25-30$ years & 26 & 9.9 & 9.9 \\
& 31 - 35 years & 50 & 19.1 & 19.1 \\
& 36 - 40 years & 88 & 33.6 & 33.6 \\
& 41 and above & 98 & 37.4 & 37.4 \\
& Total & 262 & 100.0 & 100.0 \\
\hline
\end{tabular}

Source: Field Survey, (2021).

The age distribution data presented is two hundred and sixty-two (262) respondents and it fell within four cardinal age brackets. 26 representing $9.9 \%$ of the respondents fell within the age bracket of $25-30$ years; 50 representing $19.1 \%$ of the respondents are within the ages of $31-35$ years; 88 representing $33.6 \%$ of the respondents fell within the age bracket of $36-40$ years, while 98 representing $37.4 \%$ fell within the age bracket of 41 years and above. By this age distribution, it is evident that most of the employees of the oil and gas companies in Rivers State are within the ages of 41 years and above. This is not far from the reason that most persons from age 41 and above begin to demand for job security because age is no longer on their side. Going to look for a new job at that time is not always easy and guaranteed having put in most of their youthful years in their current place of work.

Table 5 Level of Education of Respondents

\begin{tabular}{llccc}
\hline & & Frequency & Percent & Valid Percent \\
\hline Valid & OND/HND & 57 & 21.8 & 21.8 \\
& BSC & 157 & 59.9 & 59.9 \\
& PG. DEGREE & 48 & 18.3 & 18.3 \\
& Total & 262 & 100.0 & 100.0 \\
\hline
\end{tabular}

Source: Field Survey, (2021).

The educational qualification of respondents presented shows that most of the oil and gas workers are educated. (157 representing 59.9\% of the respondents) have Bachelor of Science (BSC) degree. 57 representing $21.8 \%$ of the respondents have Ordinary National Diploma (OND) and Higher National Diploma (HND) certificate; 48 representing $18.3 \%$ of the respondents have Post Graduate Degree (PG). From the distribution above, it is evident that oil and gas workers are mostly educated and makes training a lot easier.

Table 6 Years of Service of Respondents

\begin{tabular}{llccc}
\hline & Frequency & Percent & Valid Percent \\
\hline Valid & 1 - 5 Years & 131 & 50.0 & 50.0 \\
& 6 - 10 Years & 74 & 28.2 & 28.2 \\
& 11 - 15 Years & 45 & 17.2 & 17.2 \\
& 16 Years and above & 12 & 4.6 & 4.6 \\
Total & $\mathbf{2 6 2}$ & $\mathbf{1 0 0 . 0}$ & $\mathbf{1 0 0 . 0}$ \\
\hline
\end{tabular}

Source: Field Survey, (2021).

The years of experience distribution presented shows that most of the oil and gas workers (151 representing $50.0 \%$ of the respondents) have $1-5$ years of working experience; 74 representing $28.2 \%$ of the respondents have $6-10$ years working experience, 45 representing $17.2 \%$ of the respondents have $11-15$ years working experience, while 12 representing $4.6 \%$ of respondents have 16 years and above working experience.

This shows that majority of the workers are not retained and eventually leave the oil and gas companies due to lack of years of experience needed on the job. 
Table 7 Items and Score on Training

\begin{tabular}{|c|c|c|c|c|c|c|c|}
\hline \multicolumn{8}{|c|}{ Items Response Option and Scales } \\
\hline \multirow[t]{2}{*}{$\mathbf{S} / \mathbf{N}$} & Training & $\mathbf{S A}$ & $\mathbf{A}$ & $\mathbf{U}$ & $\mathbf{D}$ & SD & TOTAL \\
\hline & & 5 & 4 & 3 & 2 & 1 & \\
\hline 1. & $\begin{array}{l}\text { In my organization, employee' skills are } \\
\text { developed by organizational training in } \\
\text { other to increase their chances of being } \\
\text { promoted. }\end{array}$ & $\begin{array}{c}98 \\
(37.4 \%)\end{array}$ & $\begin{array}{c}113 \\
(50.8 \%)\end{array}$ & $\begin{array}{c}6 \\
(2.3 \%)\end{array}$ & $\begin{array}{c}20 \\
(7.6 \%)\end{array}$ & $\begin{array}{l}5 \\
(1.9 \%)\end{array}$ & $\begin{array}{c}262 \\
(100 \%)\end{array}$ \\
\hline 2. & $\begin{array}{l}\text { Training scheme enhances employee } \\
\text { performance in my organization. }\end{array}$ & $\begin{array}{c}139 \\
(53.1 \%)\end{array}$ & $\begin{array}{c}121 \\
(46.2 \%)\end{array}$ & $\begin{array}{c}2 \\
(.8)\end{array}$ & & & $\begin{array}{c}262 \\
(100 \%)\end{array}$ \\
\hline 3. & $\begin{array}{l}\text { My organization offers the necessary } \\
\text { training to do my job. }\end{array}$ & $\begin{array}{c}95 \\
(36.3 \%)\end{array}$ & $\begin{array}{c}144 \\
(55.0 \%)\end{array}$ & $\begin{array}{c}8 \\
(3.1 \%)\end{array}$ & $\begin{array}{c}15 \\
(5.7 \%)\end{array}$ & & $\begin{array}{c}262 \\
(100 \%)\end{array}$ \\
\hline \multirow[t]{2}{*}{4.} & $\begin{array}{l}\text { Several professional development } \\
\text { activities }\end{array}$ & & & & & & \\
\hline & $\begin{array}{l}\text { (Mentoring, On-the-job, Off-the-job } \\
\text { training) are offered to employee in my } \\
\text { organization to enhance their skills and } \\
\text { knowledge of the job. }\end{array}$ & $\begin{array}{c}98 \\
(37.4 \%)\end{array}$ & $\begin{array}{c}153 \\
(58.4 \%)\end{array}$ & $\begin{array}{c}6 \\
(2.3 \%)\end{array}$ & $\begin{array}{l}5 \\
(1.9 \%)\end{array}$ & & $\begin{array}{l}262 \\
(100 \%)\end{array}$ \\
\hline 5. & $\begin{array}{l}\text { My organization gives priority to } \\
\text { training and development of its } \\
\text { employee. }\end{array}$ & $\begin{array}{c}147 \\
(56.1 \%)\end{array}$ & $\begin{array}{c}108 \\
(41.2 \%)\end{array}$ & $\begin{array}{c}2 \\
(.8 \%)\end{array}$ & $\begin{array}{l}5 \\
(1.9 \%)\end{array}$ & & $\begin{array}{c}262 \\
(100 \%)\end{array}$ \\
\hline 6. & $\begin{array}{l}\text { Mentoring is done in my organization to } \\
\text { achieve a specific personal or } \\
\text { professional goal. }\end{array}$ & $\begin{array}{c}75 \\
(28.6 \%)\end{array}$ & $\begin{array}{c}167 \\
(63.7 \%)\end{array}$ & $\begin{array}{c}6 \\
(2.3 \%)\end{array}$ & $\begin{array}{c}51 \\
(19.5 \%)\end{array}$ & $\begin{array}{c}14 \\
(5.3 \%)\end{array}$ & $\begin{array}{c}262 \\
(100 \%)\end{array}$ \\
\hline 7. & $\begin{array}{l}\text { My organization is committed to the } \\
\text { training of its workforce. }\end{array}$ & $\begin{array}{c}72 \\
(27.5 \%)\end{array}$ & $\begin{array}{c}173 \\
(66.0 \%)\end{array}$ & $\begin{array}{c}12 \\
(4.6 \%)\end{array}$ & $\begin{array}{c}5 \\
(1.9 \%)\end{array}$ & & $\begin{array}{c}262 \\
(100 \%)\end{array}$ \\
\hline
\end{tabular}

Source: Field Survey, (2021).

Table 7 shows the number of responses recorded in each of the response options. For instance, on the measurement item 7 respondents were required to indicate their view whether their organization is committed to the training of its workforce. Majority (173) of the respondents said, they agree, while 72 respondents strongly agree, 12 respondents were undecided and 5 respondents said they disagree. The dominant view therefore is that the organisations understudy are committed to the training of its workforce.

Table 8 Items and Scores of Employability Skills

\begin{tabular}{|c|c|c|c|c|c|c|c|}
\hline \multirow{2}{*}{$\frac{\text { Items }}{\mathrm{S} / / \mathbf{N}}$} & \multicolumn{7}{|c|}{ Responses Option and Scales } \\
\hline & Employability Skills & SA & $\mathbf{A}$ & $\mathbf{U}$ & $\mathbf{D}$ & SD & TOTAL \\
\hline & & 5 & 4 & 3 & 2 & 1 & \\
\hline \multirow[t]{2}{*}{1.} & It creates confidence in & 167 & 90 & 5 & & & 262 \\
\hline & $\begin{array}{l}\text { employees which brings } \\
\text { about security of job. }\end{array}$ & $(63.7 \%)$ & $(34.4 \%)$ & $(1.9 \%)$ & & & $(100 \%)$ \\
\hline \multirow[t]{2}{*}{2.} & It leads to several & 157 & 105 & & & & 262 \\
\hline & opportunity. & $(59.9 \%)$ & $(40.1 \%)$ & & & & $(100 \%)$ \\
\hline 3. & $\begin{array}{l}\text { It boost the economic worth } \\
\text { of the employee. }\end{array}$ & $\begin{array}{c}90 \\
(34.4 \%)\end{array}$ & $\begin{array}{c}130 \\
(49.6 \%)\end{array}$ & $\begin{array}{c}18 \\
(6.9 \%)\end{array}$ & $\begin{array}{c}24 \\
(9.2 \%)\end{array}$ & & $\begin{array}{c}262 \\
(100 \%)\end{array}$ \\
\hline
\end{tabular}

Source: Field Survey, (2021).

Table 8 shows the number of responses recorded in each of the response options. For instance, on the measurement item 1 respondents were required to indicate their view whether employability skills creates confidence in employees which brings about security of job in their organization. Majority (167) of the respondent said, they strongly agree, while 90 respondents agreed, 5 respondents were undecided. The dominant view therefore is that skills creates confidence in employees which brings about security of job in the organisations understudy. 
Table 9 Items and Scores of Work Experience

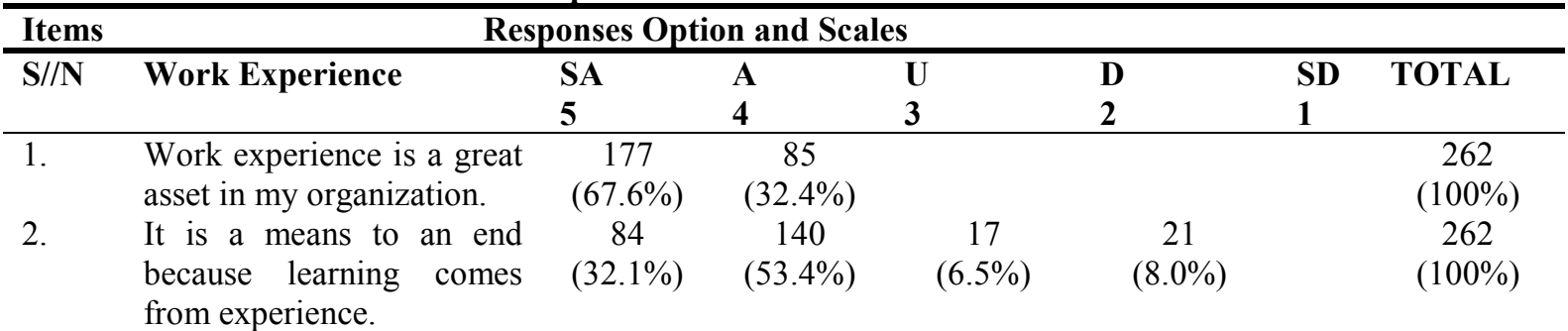

Source: Field Survey. (2021).

Table 9 shows the number of responses recorded in each of the response options. For instance, on the measurement item 1, respondents were required to indicate their view whether work experience is a great asset in their organization. Majority (177) of the respondents said, they strongly agree, while 85 respondents agreed. The dominant view therefore is that work experience is a great asset in the organisations understudy.

\section{Table 10 Items and Scores of Employment Contract}

\begin{tabular}{|c|c|c|c|c|c|c|c|}
\hline Items & $\mathbf{R e}$ & onses Op & $n$ and $S c$ & & & & \\
\hline \multirow[t]{2}{*}{$\mathbf{S} / / \mathbf{N}$} & Employment Contract & $\mathbf{S A}$ & $\mathbf{A}$ & $\mathbf{U}$ & D & SD & TOTAL \\
\hline & & 5 & 4 & 3 & 2 & 1 & \\
\hline \multirow[t]{2}{*}{1.} & Jobs are usually temporal & 48 & 79 & 29 & 106 & & 262 \\
\hline & in my organization. & $(18.3 \%)$ & $(30.2 \%)$ & $(11.1 \%)$ & $(40.5 \%)$ & & $(100 \%)$ \\
\hline \multirow[t]{2}{*}{2.} & My organization offers & 34 & 109 & 62 & 57 & & 262 \\
\hline & $\begin{array}{l}\text { permanent job contract } \\
\text { always. }\end{array}$ & $(13.0 \%)$ & $(41.6 \%)$ & $(23.7 \%)$ & $(21.8 \%)$ & & $(100 \%)$ \\
\hline \multirow[t]{2}{*}{3.} & My organization honours & $\begin{array}{c}84 \\
(3210\end{array}$ & $\begin{array}{c}140 \\
(5340 / 9)\end{array}$ & $\begin{array}{c}17 \\
(650)\end{array}$ & 21 & & 262 \\
\hline & signed contract to its latter. & $(32.1 \%)$ & $(53.4 \%)$ & $(6.5 \%)$ & $(8.0 \%)$ & & $(100 \%)$ \\
\hline
\end{tabular}

\section{Source: Field Survey, (2021).}

Table 10 shows the number of responses recorded in each of the response options. For instance, on the measurement item 3, respondents were required to indicate their view whether their organization offers permanent job contract always. Majority (140) of the respondent said, they agree, while 84 respondents strongly agree, 17 respondents were undecided and 21 respondents disagreed. The dominant view therefore is that the organisations understudy honours signed contract to its latter.

\section{Decision Rule}

If our statistical analysis shows that the significance level is below the cut-off value we have set (which is 0.05 ), we reject the null hypothesis and accept the alternate hypothesis. Alternatively, if the significance level is above the cut-off value, the null hypothesis is accepted.

In testing the hypotheses one to three, the following rules were upheld in accepting or rejecting our null hypotheses. All the coefficient ( $r$ ) values that indicate levels of significance $(*$ or $* *$ ) as calculated using SPSS were accepted and thus our alternate hypotheses were accepted and when no significance is indicated in the coefficient (r) value we reject the null hypotheses. We set out confidence interval at 0.05 level of significance to test the statistical significance of this study. We used both the significance values and the coefficient values.

\section{Hypothesis 1}

$\mathrm{HO}_{1}$ : There is no significant relationship between training and employability skills.

Table 11 Correlations of Training and Employability Skills

\begin{tabular}{llcc}
\hline & & Training & Employability Skills \\
\hline Training & Pearson Correlation & 1 & $.423^{* *}$ \\
& Sig. (2-tailed) & & .050 \\
& $\mathrm{~N}$ & 262 & 262 \\
Employability Skills & Pearson Correlation & $.423^{* * *}$ & 1 \\
& Sig. (2-tailed) & .050 & 262 \\
\hline
\end{tabular}

**. Correlation is significant at the 0.05 level (2-tailed).

Source: SPSS Output

Table 11 revealed that there is a moderate positive relationship between training and employability skills at 0.423 at a significance level of 0.50 which is equal to the chosen alpha level of 0.05 for the hypothesis. The correlation is only statistically significant at 0.05 level of significance. Therefore, with a correlation of 0.423 , we reject the null hypothesis and however accept the alternative hypothesis. This implies that there is a positive 
relationship between training and employability skills in oil and gas companies in Rivers State.

Hypothesis 2

Ho2: There is no significant relationship between training and work experience.

Table 12 Correlations of Training and Work Experience

\begin{tabular}{llcc}
\hline & & Training & Work Experience \\
\hline Training & Pearson Correlation & 1 & $.712^{* *}$ \\
& Sig. (2-tailed) & & .023 \\
Work Experience & N & 262 & 262 \\
& Pearson Correlation & $.712^{* * *}$ & 1 \\
& Sig. (2-tailed) & .023 & 262 \\
\hline
\end{tabular}

**. Correlation is significant at the 0.05 level (2-tailed).

Source: SPSS Output

Table 12 revealed that there is a very strong positive relationship between training and work experience at 0.712 at a significance level of 0.23 which is less than the chosen alpha level of 0.05 for the hypothesis. The correlation is only statistically significant at 0.05 level of significance. Therefore, with a correlation of 0.712 , we reject the null hypothesis and however accept the alternative hypothesis. This implies that there is a positive relationship between training and work experience in oil and gas companies in Rivers State.

\section{Hypothesis 3}

Ho3: There is no significant relationship between training and employment contract.

Table 13 Correlations of Training and Employment Contract

\begin{tabular}{llcc}
\hline & & Training & Employment Contract \\
\hline Training & Pearson Correlation & 1 & $.407 * *$ \\
& Sig. (2-tailed) & & .050 \\
& $\mathrm{~N}$ & 262 & 262 \\
Employment Contract & Pearson Correlation & $.407 * *$ & 1 \\
& Sig. (2-tailed) & .050 & 262 \\
& $\mathrm{~N}$ & 262 & 262 \\
\hline
\end{tabular}

**. Correlation is significant at the 0.01 level (2-tailed).

\section{Source: SPSS Output}

Table 13 revealed that there is a moderate positive relationship between training and career development at 0.407 at a significance level of 0.50 which is equal to the chosen alpha level of 0.05 for the hypothesis. The correlation is only statistically significant at 0.01 level of significance. Therefore, with a correlation of 0.407 , we reject the null hypothesis and however accept the alternative hypothesis. This implies that there is a relationship between training and employment contract in oil and gas companies in Rivers State.

\section{Discussion of Findings}

The test of hypotheses one to three revealed that training is positively correlated with the employability skills, work experience and employment contract in oil and gas companies in Rivers State. The hypotheses one to three implies that the more oil and gas companies invest in training such as on-the job training, mentoring and off-thejob-training, the more their employees get to perform better and meet the objectives and target of the organization thereby creating a bond between management and employees. This finding is in agreement with the findings of Ronald and Lideway (2006), Villegas (2006) and Abdulkadir, et al., (2012) that corporate investment in training and development is strongly and positively connected with psychological traits such as job satisfaction, intention to stay and employee satisfaction. Training in addition to making employee become efficient in their jobs, makes the employee feel vital and valued by his employer. Employees are likely to work more productively and committed if they are happy with the organization.

\section{Conclusions}

Based on the analyses of data and discussion of findings, the study concluded that training affects job security. Training offers both economic and psychological relief for members of a company which makes them feel appreciated. Therefore, any oil and gas company that is devoid of well-organized training, will experience low employee retention and significant rise in workers' intention to quit.

\section{References}

Abdulkadir, D. S., Isiaka, S. B., \& Adedoyin, S. I. (2012). Effects of strategic performance appraisal, career planning and employee participation on organizational commitment: An empirical study. International Business Research, 5(4), 124. 
Adebayo, O. I., \& Lucky, O. I. E. (2012). Entrepreneurship development and national job security. Proceedings of the LASPOTECH SM National Conference on National Job Security Main Auditorium, June 25-26, 2012, Isolo Campus, Lagos, Nigeria.

Ash, R. A., \& Levine, E. L. (2015). Job applicant training and work experience evaluation: An empirical comparison of four methods. Journal of Applied Psychology, 70(3), 572.

Becker, B. E., \& Huselid, M. A. (2006). Strategic human resources management: where do we go from here? Journal of Management, 32(6), 898-925.

Blair, D., \& Sisakhti, R. (2007). Sales training: What makes it work? T+D Magazine, August. Available at: www.astd.org/astd/Publications/TDMagazine/2007pdf/August/0708ExecSumhtm

Brown, P., \& Hesketh, A. (2004). The mismanagement of talent: Employability and jobs in the knowledge economy. Oxford University Press.

Business dictionary, (2013b). Job security. http://www.businessdictionary.com/definition/job-security.html

Campion, M. A., Cheraskin, L., \& Stevens, M. J. (2014). Career-related antecedents and outcomes of job rotation. Academy of Management Journal, 37(6), 1518-1542.

Chang, K. (2008). The theory of labour contract law's legislation basis and legal position. Law Review, 2, 5-14.

Deloitte, E. (2010). Employability: A review and analysis of the assessment/recognition processes that are used to accredit and otherwise measure the development of employability skills - both for individuals and for institutions London, UK Commission for Employment and Skills.

Fey, C. F., Bjorkman, I., \& Pavlovskaya, A. (2017). The effect of human resource management practice on firm performance in Russia. International Journal of Human Resource Management, 11, 1-18.

Ford, J. K., Quiñones, M. A., Sego, D. J., \& Sorra, J. S. (2012). Factors affecting the opportunity to perform trained tasks on the job. Personnel Psychology, 45(3), 511-527.

Gold, M. (2001). Breaking all the rules for recruitment and retention. Journal of Career Planning and Employment, 61(3), 6-8

Gomez-Mejia, L. R., Balkin, D. B., \& Cardy, R. L. (2005). Managing human resources. Prentice-Hall Inc.

Harrison, R. (2015). Learning and development. Development and learning in organizations An International Journal, 26(1), 35-39.

Hiltrop, J. (2019). The quest for the best: Human resource practice to attract and retain talent. European Management Journal, 17, 422-430.

Hind, D., \& Moss, S. (2011). Employability skills. (2nd Ed). Business Education Publishers.

Hofmann, D. A., Jacobs, R., \& Gerras, S. J. (2012). Mapping individual performance over time. Journal of Applied Psychology, 77(2), 185 .

Huselid, M. A. (2011). Celebrating 50 years: Looking back and looking forward: 50 years of human resource management. Human Resource Management, 50(3), 309.

ILO, (2013). Employability skills and retention, 1985 (No. 4) [Internet]. http://www.ilo.org/dyn/normlex/en/f?p=NORMLEXPUB:12100:::NO:1210 0:P12100 ILO CODE:R004:NO

Juliane, V. (2020a). 7 Skills that make you a better employee, no matter your job. https://www.hercampus.com/money-career/how-be-better-employee-impress-employers

Kalleberg, A. L., \& Rognes, J. (2000). Employment relations in Norway: Some dimension and correlates. Journal of Organizational Behaviour, 21, 315-335.

KPMG, (2010). Recent study reveals job security more important than pay and benefits for university students. http://staceybrandall.wordpress.com/2010/04/06/april-2010-recent-study-reveals-job-security-moreimportant-than-pay-and-benefits-for-university-students/

McCall, M. W., Lombardo, M. W., Lombardo, M. M., \& Morrison, A. M. (2008). Lessons of experience: How successful executives develop on the job. Simon and Schuster.

Messmer, M. (2000). Orientations programs can be key to employee retention. In Strategic Finance. 81 (8), $12-$ 15.

Michael, C. (2019). Types of employment contracts. https://www.reed.co.uk/career-advice/types-of-employmentcontracts/

Noe, R., Hollenbeck J., Gerhart, B., \& Wright, P. (2015). Human Resource Management, Gaining Competitive Advantage. (6 ${ }^{\text {th }}$ ed) McGraw-Hill Irvin.

Oregon-Sanchez, A., Barba-Aragon, I., \& Sanz-Valle, R. (2017). Effects of training on business results. International Journal of Human Resource Management, 14, 956-80.

Remington, T. F., \& Cui, X. W. (2019). The impact of the 2008 labour contract law on labour disputes in China. Journal of East Asian Studies, 15(2), 271-299.

Roehling, M. V., Cavanaugh, M. A., Moynihan, L. M., \& Boswell, W. R. (2000). The nature of the new employment relationship: A content analysis of the practitioner and academic literatures. Human Resource Management, 39, 305-320. 
Ronald, C. V., \& Lidewey, E. C. (2006, October). Empirical evidence for positive effects of training and developmental opportunities on work attitudes of employees in the public sector. Paper presented at the International HRD Conference, Amsterdam. https://www.researchgate.net/publication/254820541

Saravanan, V. (2009). Sustainable employability skills for engineering professionals. The Indian Review of World Literature in English, 5 (11), 200.

Schappel, C. (2012). Top 10 job factors that attract, retain employees. http://www.hrmorning.com/top-10-jobfactors-that-attract-retain-employees/

Smith, P. J. \& De Cronje, G. J. (2013). Management principles. Juta.

Tomlinson, A. (2002). High technology workers want respect, Survey Canadian Human Resources Reporter, 15(3), 2.

TW, (2010). Malaysians value job security and stability. http://www.towerswatson.com/press/1585

Villegas, R. (2006). Training is not enough. http://www.- saipantribune.com/newsstory.aspx?newsID=62172 \&cat $=3$

Warnich, S., \& Grobler, P. A. (2016). Human resource development (HRD) practice in local vs foreign companies in South Africa: Is there a difference? Journal of Contemporary Management, 13(1), 702-724.

Wood, S., \& De Menezes, L. (2008). High commitment management in the UK: Evidence from the workplace industrial relations survey, and employers' manpower and skills practice survey. Human Relations, 51(4), 485-515.

Zhu, Y., \& Campbell, I. (2002). Individual Labour Contracts in People's Republic of China enterprises. International Journal of Comparative Labour Law and Industrial Relations 18(1), 5-14. 